\title{
気管側からみた正常声帯の振動様式
}

\author{
湯本 英二・黒川 浩伸・丘村＼cjkstart熙

\section{Infraglottic View of Normal Vocal Fold Vibration}

\author{
Eiji Yumoto, Hironobu Kurokawa and Hiroshi Okamura
}

(Ehime University)

\begin{abstract}
We examined normal vocal fold vibration from the tracheal side in 4 canine larynges by ultra-high speed cinematography. The larynx was fixed to the hole of a glass box. Then air was delivered to the glass box, representing subglottic space, for phonation. After cinematography, two of the four larynges were sectioned in a frontal plane and used for histologic examination. Mucosal upheaval appeared on a lower surface of the vocal fold during vibration. Mucosal vibration occurred from the mucosal upheaval, which vibrated with a small amplitude and with an earlier phase than the free edge of the vocal fold. The mucosal upheaval shifted upward when the vocal fold vibrated at a higher frequency. Histologic examination revealed that the mucosal upheaval arose on the lower surface of the vocal fold between the free edge and the area where the muscular layer came close to the epithelial layer.
\end{abstract}

Key words: vocal fold vibration, lower surface of the vocal fold, high speed movie, mucosal upheaval

はじめに

発声中の声帯振動の解析には，声帯上面だけ でなく声帯下面の観察も必要である.しかし声 帯は甲状軟骨・輪状軟骨の枠組みの中にあり, しか屯吹鳴のためには気管側から送気するとい う操作を要するので振動声帯下面の観察は容易 でない，そのため小鉊片を声帯に刺入してX線 ストロボスコピーを用いて前額面から声帯下面 の振動様式を観察するなどの工夫がなされてき た 鳴が非生理的にならないよう留意して声帯振動 を気管側から高速度映画に撮影した。 今回，犬 摘出喉頭を用いて声帯下面の正常声帯振動を観 察し若干の知見を得たので報告する.

\section{実験方法}

実験には成犬の正常摘出喉頭 4 個を用いた. 声帯を上下両方向から観察するために，上方は 仮声帯までを切除し，下方は輪状軟骨下端で第 一気管輪と切断した。

吹鳴に必要な声門閉銷を得るために両側披裂 軟骨声帯突起部を 4-0 ナイロン糸で縫合した。 実験に用いた 4 個の喉頭の内 2 個は声帯膜様部 前後軸のほぼ中央で，遊離縁からやや外側（犬 C）抢よび外側（犬D）の声帯下面にピオクタ ニンあるいは墨汁を用いて $27 \mathrm{G}$ 針で標識した。

次に，声帯上面を外に向けて喉頭をガラス箱 にあけた小孔に固定した．固定には粘土を用い て小孔内の喉頭とガラス箱の間に気密を保つよ

愛媛大学医学部耳鼻咽喉科学教室（主任：柳原尚明教授） 
うにした (図 1). 加湿した空気を一定の流量で ガラス箱に流し，それによって喉頭を吹鳴させ た。喉頭を固定したガラス面の対側のガラス面 を通して声带下面を毎秒約5000駒で高速度映画 に撮影した (Hymac，日立). 撮影の直後む撮 影時と同じ条件で吹鳴をしばらく持続させて吹 鳴音をテープに録音し振動数を測定した。

撮影後，声帯下面の標識点に遊離縁と平行に 11号メスで小切開を加え，10\%ホルマリンで喉 頭を固定した。標本は脱灰の後，前額断に薄切 し HE 染色およびアザン染色を施し，光学顕 微鏡下に観察した。この操作は, 声帯振動時に のみ出現するヒダ状粘膜隆起の位置が非振動時 の喉頭のどの部分に相当するかを検討するため

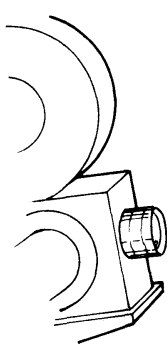

高速度カメラ
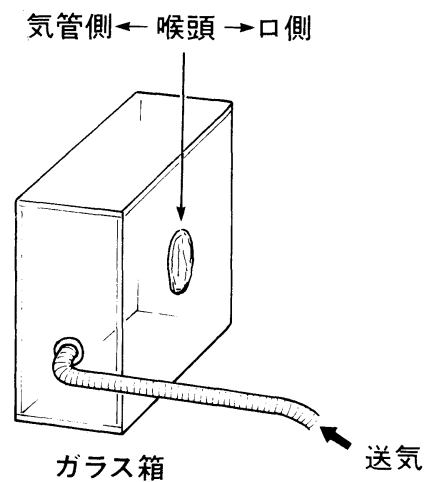

図 1 声帯振動の観察法. 声帯上面を外に向けて喉頭 をガラス箱にあけた小孔に固定した。加湿した 空気を一定の流量でガラス箱に流し，それによ って喉頭を吹鳴させた．喉頭を固定したガラス 面の対側のガラス面を通して声帯下面を高速度 映画に撮影した。

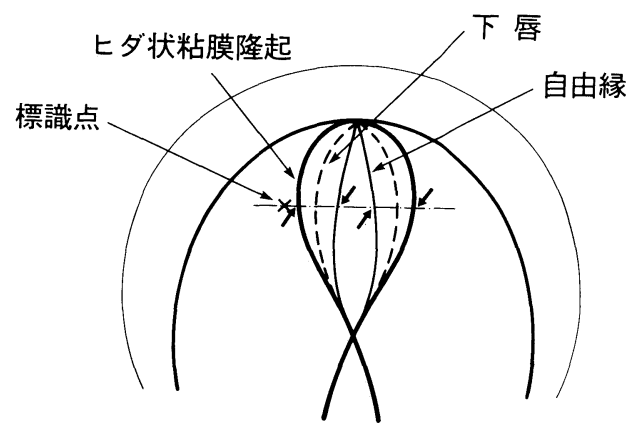

図 2 開大期の声帯下面の模式図. 矢印は分析点 を示す。
に行なった。

撮影フイルムは通常の速さで映写して声帯振 動を観察した後, Film motion analyzer (Model MC-08，Nac）を用いて1 駒ごとに分析した. 分析点は，声帯前後軸に垂直で標識点を通る直 線が両側声帯自由縁, 両側のヒダ状粘膜隆起 交差する点である (図 2 , 矢印). 犬 A, B は標 識がないので振幅が最大となる中央部で下唇の 運動もあわせて測定した。 また，犬Cでは標識 点の動きも分析した. な扔, 分析に際して声帯 下面の振動部分（声帯下面の膜様部といえる） の前後長を基準（100）として正中線から垂直に 各点までの距離を測定した。

\section{結果}

\section{（1）気管側からみた声帯振動}

代表例として図 3 に犬Aの振動を示す，吹鳴 音の振動数は $191 \mathrm{~Hz}$ であった. 上が左側, 下 が右側で，外側から順にヒダ状粘膜隆起，下唇， および遊離縁の動きを表わす。下唇と遊離縁が 重なった区間では下唇が遊離縁となっている。

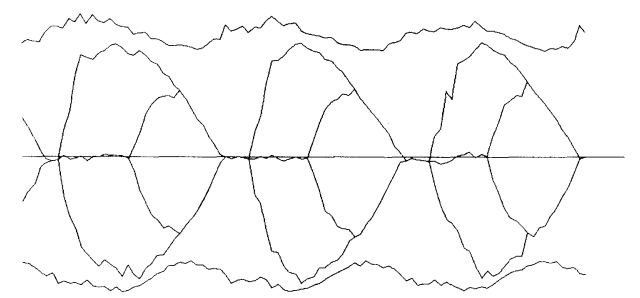

図 3 犬 Aの振動.上が左側, 下が右側で，外側から 順にヒダ状粘膜隆起，下唇，遊離縁の動さを表 わす.下唇と遊離縁が重なった区間では下唇が 遊離縁となっている。

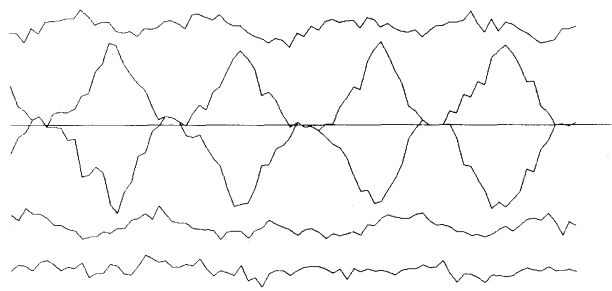

図 4 犬Cの振動. 上が左側, 下が右側で, 左側は外 側から順にヒダ状粘膜隆起, 遊離縁の動きを, 右側はヒダ状粘膜隆起の外側にさらに標識点の 動きを示す. 
ヒダ状粘膜隆起，下唇，遊離縁と屯動きはほぼ 対称的で，異なった周期間の変動もみられなか った，閉小期に，下唇は遊離縁となって内方へ 移動し左右が正中で激しく衝突して閉鎖期にな った，衝突の直後，下唇は速やかに外下方へ移 動し，閉鎖期の間外側に留まっていた。乙の間 は下唇を同定しづらい場合があった。 その後遊 離縁が外方移動を開始するときに一致して（開 大期の初期), 下唇が内方への動き開始した. やがて下唇が再び遊離縁となって, 振動は開大 期から次の周期の閉小期に入った。な拉，声帯 振動は声帯と声門下腔との間に生じた段差すな わちヒダ状粘膜隆起の内上方で起こった。 下唇 の外方移動はこのヒダ状粘膜隆起あるいはその すぐ内側まで到達した。 また，上ダ状粘膜隆起 自身屯，振幅は小さいが遊離縁の動きに同期し てそれより早い位相で振動していた。

図 4 亿犬Cの振動を示す。分析点は中央より やや後方で, 吹鳴音の振動数は $285 \mathrm{~Hz}$ であっ た。 上が左側，下が右側で，左側は外側から順 にヒダ状粘膜隆起, 遊離縁の動きを, 右側は七 ダ状粘膜隆起の外側に標識点の動きを表わす. ヒダ状粘膜隆起は，犬A と同様，振幅は小さい が遊離縁の動きに同期してそれより早い位相で 振動していた，標識点はヒダ状粘膜隆起のやや 外側に位置していた．乙の点はヒダ状粘膜隆起 より小さな振幅でかつ遅れた位相で動いてい た. 七ダ状粘膜隆起の振動が一部, 外下方に伝 播したものと考えられた。 犬Dに㧍ける標識点 は七ダ状粘膜隆起からかなり外側に位置したの で標識点の分析は行なわなかった。
（2）七ダ状粘膜隆起の位置

ヒダ状粘膜隆起は声帯振動時にのみ出現し, 非振動時には観察されない. 非振動時の喉頭を 固定して作製した標本上で、ダ状粘膜隆起がご こに相当するかを検討した。

実験に用いた 4 個の喉頭について, 吹鳴音の 振動数, 振動分析を行なった部位, 両側遊離縁 の振幅, 両側七ダ状粘膜隆起の位置および標識 点の位置（犬C，D）を表 1 亿示した。表から わかるように振動数が小さいほどヒダ状粘膜隆 起は外側に生じた。 犬 A， Bのヒダ状粘膜隆起 は犬Dのそれの位置に比して正中線から約 2 倍 の距離に位置していた。また，ヒダ状粘膜隆起 と同様，振動数が小さい方が遊離縁の振幅が大 きかった。
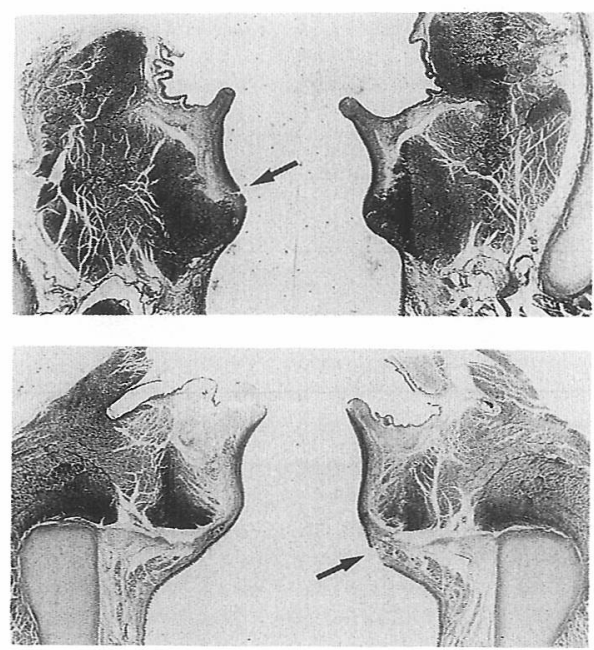

図 5 前額断の喉頭標本 (上: 犬 $\mathrm{C}$, 下 : 犬D, アザ 染色). 矢印は標識点に加えた切創を示す.

表 1 吹鳴音の振動数, 振動分析を行なった部位, 遊離縁の振幅, ヒダ状粘膜隆 起の位置および標識点の位置

\begin{tabular}{|c|c|c|c|c|c|c|c|}
\hline \multirow{2}{*}{ 犬 } & \multirow{2}{*}{$\begin{array}{c}\text { 振動数 } \\
(\mathrm{Hz})\end{array}$} & \multirow{2}{*}{ 測定部位 } & \multicolumn{2}{|c|}{ 遊離縁の振幅 } & \multicolumn{2}{|c|}{ ヒダ状粘膜隆起 } & \multirow{2}{*}{ 標 識点 } \\
\hline & & & 右 & 左 & 右 & 左 & \\
\hline A & 191 & 中 & 12.4 & 10.7 & 21.8 & 22.0 & - \\
\hline B & 129 & 中 央 & 9.7 & 10. 1 & 20.1 & 18.8 & $\longrightarrow$ \\
\hline $\mathrm{C}$ & 285 & やや後方 & 4.7 & 4.8 & 8.9 & 8.1 & 12.7 (右) \\
\hline $\mathrm{D}$ & 465 & 中 央 & 6.7 & 6.7 & 9.3 & 11.5 & 28.3 (左) \\
\hline
\end{tabular}


犬 C，Dの前額断喉頭大切片標本を図 5 に示 す (アザン染色). 犬Cの右声帯下面の切創は (図 5 上，矢印)，粘膜固有層が薄くなり上皮層 が筋層と最も接近した部分のやや上方に認めら れた。 犬Dの左声帯下面の切創は（図 5 下，矢 印), 粘膜固有層の最屯薄い部分の下方に認め られた，高速度映画の分析から得られたヒダ状 粘膜隆起の位置（表 1 参照）と考元わせると， ヒダ状粘膜隆起は，上皮層と筋層が最も接近し た部位より上方に生じたといえる。また，振動 数が大きい方がより上内方に生じた， 2 個の標 本と屯声带下面の振動の生じる部分は, 筋層か ら離れ，疎な結合組織からなる部分で，上皮層 と筋層が最も接近した部位より上方であった。

\section{考按}

嗄声に対する外科的治療として，顕微鏡下喉 頭微細手術いわゆるラリンゴマイクロ ${ }^{2)}$ の行な われることが多い3). 喉頭内腔からのアプロー チによって病変を摘出する操作が主となる，病 変除去後の創は二次的な治瘾過程をたに゙るの で，手術操作による組織欠損部は痽痕に置換さ れることになる。この瘢痕が大きい場合はもち ろん，小さくても部位によっては術後の声帯振 動が障害される可能性がある。乙の意味で，ラ リンゴマイクロ施行後に確実に嗄声を改善せし めるためには，正常声帯の振動様式を十分に理 解している必要がある。しかし，声帯下面の振 動様式については研究が少なく詳細は未だ解明 されていない，松下4) は，犬摘出喉頭を用いて 撮影した高速度映画の定性的な観察に基づい て, 声帯の振動部分はヒダ状粘膜隆起の内上方 であると報告した。斉藤1 はヒトあるいは犬摘 出喉頭に小鉛片を刺入しX線ストロボスコピー を用いて前額面から声帯振動を観察した。その 結果, 下唇よりも 1 2 mm 下方に隆起が出現 し, 声帯自由縁より早い位相でわずかに振動す るととを報告した. Baer ${ }^{5)}$ は，声帯下面に置い た微粒子の前額面上での動きをストロボスコピ 一を用いて観察し，微粒子はおもに水平方向に 運動したと報告した。乙の結果はX線ストロボ
スコピー法による川崎の研究結果 ${ }^{6)}$ と一致して おり，本研究のように高速度映画撮影によって 気管側からの声帯振動の観察，特に水平方向の 詳細な分析を行なうことの重要性を示してい る. 福田 ${ }^{7)}$ は, 摘出喉頭の頭側に接続した管を 通して声門上に陰圧をかけることによって喉頭 を吹鳴して観察し，声門下の振動部分はごく狭 かったとしている。しかしての吹鳴法は, 通常 の，気管側からの送気による吹鳴に比して非生 理的であり，とりわけ起声時において，正常の 振動様式と異なる可能性がある。本研究では, 犬摘出喉頭を用いて，鉛片などの負荷を排しか

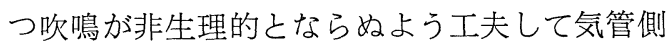
から声帯振動を高速度映画に撮影した。また， 声帯下面の標識点を，振動分析の対象とすると 同時にヒダ状粘膜隆起の解剖学的位置の推定に 際しての目印とした。

気管側からみた声帯振動は上述の 報告1)4) 7) とほぼ同様であった。閉小期に，下唇は遊離縁 となって内方へ移動し左右が正中で激しく衝突 して閉鎖期にはいる。 下唇として観察されてい た粘膜隆起は，大部分がそのまま上方，やがて 上外方へ移動し，口側から上唇として観察され るようになる。一方，衝突によって進行波の一 部は反射して再び外下方へ伝播する粘膜隆起と なる. この粘膜隆起が閉鎖期初期にみられる下 唇である。従って開大期にみられた下唇よりあ 閉鎖期初期の下唇の方が隆起が低いので同定し づらい.

ヒダ状粘膜隆起は，斉藤の述べたように1， 声帯自由縁と同期してそれより早い位相で振幅 の小さい振動をしていた。 また，ヒダ状粘膜隆 起のやや外側の標識点（犬C）は七ダ状粘膜隆 起より小さな振幅かつ遅れた位相でわずかに動 いていた。しかしての動きはヒダ状粘膜隆起の 運動の一部が下方に伝播したあのにすぎないて とは高速度映画の観察から明らかであった。乙 れらから，声帯の振動部分はヒダ状粘膜隆起の 上方であると結論した。従って声帯の手術操作 時にはヒダ状粘膜隆起の生じる部位をできるだ 
け傷害しないととが望まれる。しかしながら， ヒダ状粘膜隆起の位置は一定でなく，表 1 亿示 すように振動数が小さいほど外下方に生じると いう傾向がある。また，標識点に加えた小切開 を目印にして組織標本上でヒダ状粘膜隆起の生 じた位置を推定したところ，上皮層と筋層が最 あ接近した部位より上方であると考えられた。 本研究では非振動時の声帯を固定したので振動 時の声帯とは形態に若干の差が生じる。さら に, 固定, 包埋, 薄切の過程で標本の形態に変 化の生じた可能性もあるのでヒダ状粘膜隆起の 位置を各々の場合で特定することはできない. 今後，同一喉頭で振動数が異なるように種々の 条件下で吹鳴することによってヒダ状粘膜隆起 の生じる位置の変化を詳細に検討する予定であ る.

\section{まとめ}

吹鳴が非生理的にならないように工夫して声 帯振動を気管側から高速度映画に撮影し，声帯 下面の振動様式を観察した。また実験に用いた 4 個の犬喉頭のうち 2 個の喉頭は前額断の組織 標本を作製し，振動時に観察されたヒダ状粘 膜隆起の位置について検討し，以下の結果を 得た.

（1）振動中，声帯下面にヒダ状粘膜隆起が出 現し，声帯振動はこれより上方で起こった。

（2）七ダ状粘膜隆起は，振幅は小さいが遊離 縁の動きに同期してそれより早い位相で振動 した.

（3）ヒダ状粘膜隆起は振動数が大きい方がよ
り内上方に生じた。

（4）喉頭の前額断標本上では，ヒダ状粘膜隆 起は上皮層と筋層が最も接近した部位より上方 に生じた。

\section{参考文献}

1）斉藤成司 : 発声機構の基礎的研究および喉頭内腔 への臨床的アプローチ. 耳鼻 23補 $1: 177 \sim 189$, 1977.

2 ）斉藤成司，荻野巳人，石倉幹雄，他：喉頭内視鏡 下の MICROSURGERY. 日気食会報 $17: 253$ 〜266, 1966.

3 ）湯本英二：音声外科の立場加ら一声带への手術侵 襲と術後の声帯振動一. 音声言語医学 $29: 203$ 207, 1988.

4）松下英明：高速度映画による摘出喉頭における声 帯振動に関する実験的研究. 耳鼻 $15: 127 \sim 142$, 1969.

5 ) Baer $T:$ Investigation of the phonatory mechanism. Proceedings of the conference on the assessment of vocal pathology (ed by Ludlow C and Hart M). ASHA Reports П. pp 38 47, Rockville, 1981.

6) 川崎順久：多面的観察による声带振動の基礎的研 究. 日気食会報 $39: 476 \sim 492 ， 1988$.

7 ）福田宏之：声带粘膜の可撓性を考慮した手術的ア プローチ．音声外科における最新の進歩（平野 実編). 29 62頁, 医学教育出版社, 東京, 1984.

$$
\left.\begin{array}{l}
\text { 原稿採択 : 平成元年 } 3 \text { 月 } 20 \text { 日 } \\
\text { 別刷請求先 : 湯本英二 } \\
\text { 个791-02 愛媛県温泉郡重信町志津川 } 454 \\
\text { 愛媛大学医学部耳鼻咽喉科学教室 }
\end{array}\right)
$$

